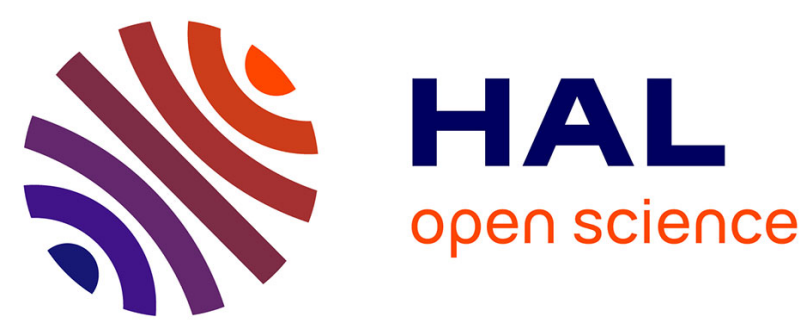

\title{
Evolution of pastoralism in Southern Greenland during the last two millennia reconstructed from bile acids and coprophilous fungal spores in lacustrine sediments
}

Typhaine Guillemot, Renata Zocatelli, Vincent Bichet, Jérémy Jacob, Charly Massa, Claude Le Milbeau, Hervé Richard, Emilie Gauthier

\section{To cite this version:}

Typhaine Guillemot, Renata Zocatelli, Vincent Bichet, Jérémy Jacob, Charly Massa, et al.. Evolution of pastoralism in Southern Greenland during the last two millennia reconstructed from bile acids and coprophilous fungal spores in lacustrine sediments. Organic Geochemistry, 2015, 81, pp.40-44. 10.1016/j.orggeochem.2015.01.012 . insu-01115614

\author{
HAL Id: insu-01115614 \\ https://hal-insu.archives-ouvertes.fr/insu-01115614
}

Submitted on 12 Feb 2015

HAL is a multi-disciplinary open access archive for the deposit and dissemination of scientific research documents, whether they are published or not. The documents may come from teaching and research institutions in France or abroad, or from public or private research centers.
L'archive ouverte pluridisciplinaire HAL, est destinée au dépôt et à la diffusion de documents scientifiques de niveau recherche, publiés ou non, émanant des établissements d'enseignement et de recherche français ou étrangers, des laboratoires publics ou privés. 


\section{Accepted Manuscript}

Note

Evolution of pastoralism in Southern Greenland during the last two millennia reconstructed from bile acids and coprophilous fungal spores in lacustrine sediments

Typhaine Guillemot, Renata Zocatelli, Vincent Bichet, Jérémy Jacob, Charly Massa, Claude Le Milbeau, Hervé Richard, Emilie Gauthier

PII: S0146-6380(15)00024-8

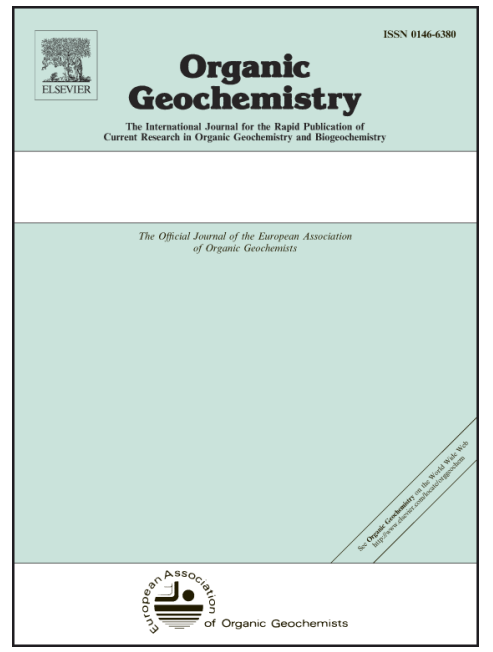

DOI: http://dx.doi.org/10.1016/j.orggeochem.2015.01.012

Reference: OG 3233

To appear in:

Organic Geochemistry

Received Date:

30 September 2014

Revised Date:

27 January 2015

Accepted Date:

30 January 2015

Please cite this article as: Guillemot, T., Zocatelli, R., Bichet, V., Jacob, J., Massa, C., Milbeau, C.L., Richard, H., Gauthier, E., Evolution of pastoralism in Southern Greenland during the last two millennia reconstructed from bile acids and coprophilous fungal spores in lacustrine sediments, Organic Geochemistry (2015), doi: http://dx.doi.org/ 10.1016/j.orggeochem.2015.01.012

This is a PDF file of an unedited manuscript that has been accepted for publication. As a service to our customers we are providing this early version of the manuscript. The manuscript will undergo copyediting, typesetting, and review of the resulting proof before it is published in its final form. Please note that during the production process errors may be discovered which could affect the content, and all legal disclaimers that apply to the journal pertain. 


\section{Evolution of pastoralism in Southern Greenland during the}

last two millennia reconstructed from bile acids and coprophilous fungal spores in lacustrine sediments

Typhaine Guillemot ${ }^{\mathrm{a},{ }^{*}}$, Renata Zocatelli ${ }^{\mathrm{b}, \mathrm{c}, \mathrm{d}},{ }$, Vincent Bichet $^{\mathrm{a}}$, Jérémy Jacob ${ }^{\mathrm{b}, \mathrm{c}, \mathrm{d}}$, Charly Massa $^{a}$, Claude Le Milbeau ${ }^{\mathrm{b}, \mathrm{c}, \mathrm{d}}$, Hervé Richard $^{\mathrm{a}}$, Emilie Gauthier $^{\mathrm{a}}$

a Laboratoire Chrono-environnement, Université de Franche Comté, CNRS UMR 6249, 16 route de Gray, 25030 Besançon, France.

${ }^{\mathrm{b}}$ Université d'Orléans, ISTO, UMR, 7327, 45071, Orléans, France

${ }^{\circ}$ CNRS/INSU, ISTO, UMR 7327, 45071, Orléans, France

${ }^{\mathrm{D}}$ BRGM, ISTO, UMR 7327, BP 36009, 45060, Orléans, France

${ }^{*}$ Cor responding author.

E mail address: typhaine.guillemot@iniv-fcomte.fr (T.Guillemot).

\section{ABSTRACT}

To reconstruct the evolution of livestock in SW Greenland over the last two millennia, we measured the concentration of bile acids in a sedimentary sequence retrieved from Lake Igaliku. Deoxycholic acid (DOC) was the sole bile acid. and was present throughout the sequence.

The DOC flux correlated quantitatively with that of coprophilous fungal spores. Maximum DOC and coprophilous fungal spores fluxe was recorded during the two periods of human settlement and grazing activity in the region (i.e. the Norse settlement during the Middle Ages and the recent Danish agricultural phase since 1920). These flux values were consistent with the presence of recent livestock around the lake and are attested to by way of archaeological data relating to the Norse period. In contrast, the DOC and coprophilous fungal spores background during pre-Norse times and the Little Ice Age (LIA), indicated the presence of wild herbivores. 
Lower DOC and coprophilous fungal spore fluxes values after the Norse abandonment, compared with pre-colonization conditions, could indicate that Norse activity in conjunction with climate pejoration, altered durably the pristine wildlife.

Therefore, these quantitative correlations between DOC and coprophilous fungal spores fluxes potentially suggest a quantitative relationship with the livestock grazing in the catchment. The comparison between sedimentary DOC and coprophilous fungal spores provides tremendous highlights on past pastoral dynamics over the last $2000 \mathrm{yr}$ in SW Greenland.

Keywords: Greenland, Norse, pastoralism, lake sediments, deoxycholic acid, coprophilous fungal spores.

\section{Introduction}

Human land use is a driver of the most recent transformations of continental ecosystems but determining the timing, intensity and distribution of human impact remains challenging. Lake deposits are one of the most appropriate archives to trace recent and past land use, because of their sensitivity of environmental change recorded at high time resolution. However, in only rare cases, may unequivocal tracers of human activity allow disentangling of natural events from human induced impact. Recent studies have proposed new biomarkers for reconstructing the history of agriculture (Oldfield et al., 2003; Jacob et al., 2008; Lavrieux et al., 2013. Concerning pastoralism, coprophilous fungal spores in sediments attest to 
grazing pressure in the catchment (Van Geel et al., 2003; Gauthier et al., 2010). They do not, however, enable the respective contributions of domestic and wild fauna to be distinguished. Fossil DNA offers a new perspective (Giguet-Covex et al., 2014) but necessitates further developments. Thus, there is no indicator which can be used to characterize a livestock population in a lake catchment. Faecal biomarkers, such as sterols and bile acids, may be biomarkers for tracing the presence of humans and grazing mammals. Furthermore, they have proved their relative resistance to degradation and ability to allow identification of domestic mammalian species (Bull et al., 2002; Elhmmali et al., 1997; Jardé et al., 2007; Tyagi et al., 2008). However, they have rarely been applied to sedimentary lacustrine records spanning several millennia (D’Anjou et al., 2012). Here, we have analyzed bile acids in the sediments of Lake Igaliku (Southern Greenland), which cover the last $1700 \mathrm{yr}$. The history of Southern Greenland constitutes an exceptional model since the pristine ecosystem was first affected by the Norse settlement during the medieval period. The region was then abandoned before the recent reintroduction of agriculture by the Danes. We tested deoxycholic acid (DOC) stability in sediments and whether or not fluxes of DOC allow reconstructing the evolution of domestic and wild fauna during the last $1700 \mathrm{yr}$ in Southern Greenland, considering natural and anthropogenic forcing. 


\section{Setting}

Lake Igaliku [61000' $\mathrm{N}, 4^{\circ} 26^{\prime} \mathrm{W}, 15 \mathrm{~m}$ above sea level (a.s.l)] is a small lake (34.6 ha), with a maximum depth $26 \mathrm{~m}$ and catchment area 3.55 $\mathrm{km}^{2}$. It is in southwestern Greenland, ca. $1.5 \mathrm{~km}$ from the village of Igaliku (Fig. 1). It has no major inflow but there is a small outflow into the Tunulliarfik fjord. It is surrounded by relatively low relief and slopes, allowing the establishment of farms, pastures and hay fields (Fig. 1). Southern Greenland has been affected by two phases of agricultural expansion during the last $1700 \mathrm{yr}$. The first corresponds to the Norse settlement that began in $986 \mathrm{AD}$ and lasted approximately until the middle of the $\mathrm{XV}^{\text {th }}$ century, coincident with the cooling of the Little Ice Age (Dugmore et al., 2012; Massa et al., 2012). The second corresponds to the modern agricultural expansion since 1920, resulting from the desire of the Danish to favour a new introduction of agricultural activities in a favorable climatic context. Nowadays, husbandry in the catchment is limited to two farms established during the 1970s where only sheep are raised (Massa et al., 2012).

\section{Material and methods}

Two cores Iga-2007 (130 cm length) and Iga-2011 (87 cm) were retrieved a few m apart under $21 \mathrm{~m}$ water depth, using a gravity corer. The age-depth model of Iga-2007 was based on 14 accelerator mass spectrometry (AMS) radiocarbon dates and on ${ }^{210} \mathrm{~Pb}$ and ${ }^{137} \mathrm{Cs}$ measurements using spectroscopy, for the upper $15 \mathrm{~cm}$ (Massa et al., 2012; Fig. 2). The model was 
applied to Iga-2011 by correlating magnetic susceptibility data (measured with a Geotek Multi Sensor Core Logger) with Iga-2007 (Fig. 2). Coprophilous fungal spores, particularly Sporormiel/a spp, were counted in 33 samples spanning the last $1700 \mathrm{yr}$ in Iga-2007, (Gauthier et al., 2010) and were expressed as flux of number of spores $\left(\mathrm{N} / \mathrm{cm}^{2} / \mathrm{an}^{1}\right)$ in order to take into account variation in sedimentation rate. Sediment samples $(35 ; 0.5 \mathrm{~cm}$ thick) from Iga-2011 were selected for biomarker analysis.

Lipids were extracted from each sample (ca. 2g) using an ASE 200 (Dionex(C) with $\mathrm{CH}_{2} \mathrm{Cl}_{2}: \mathrm{MeOH}(9: 1 \mathrm{v} / \mathrm{v})$ at $100{ }^{\circ} \mathrm{C}$ and 1000 psi. Considering the minor mineralogical changes through the core, we did not use recovery standards for the bile acid. In addition, in-house tests indicated no significant proportion of bound acids, thereby excluding bias due to the proportion of bound vs. free bile acids. The extract was separated into neutral, acidic and polar fractions using solid phase extraction on aminopropyl bonded silica (Jacob et al. 2005). The acid fraction was methylated with anhydrous $\mathrm{MeOH} / \mathrm{MeCOCl}$ and heating at $55{ }^{\circ} \mathrm{C}$ for $1 \mathrm{~h}$. After the separation of the fatty acidmethyl esters (eluted with dichloromethane, DCM) from the hydroxy acid methyl esters (eluted with DCM:MeOH 1:1) on activated silica; the latter were silylated by reacting with $100 \mu \mathrm{l}$, O-bis(trimethylsilyl)trifluoroacetamide (BSTFA) in $200 \mu \mathrm{l}$ pyridine at $60{ }^{\circ} \mathrm{C}$ during $1 \mathrm{~h}$. Finally, esterified and silylated acidic fractions were analyzed using gas chromatography-mass spectrometry (GC-MS) with a Trace GC Ultra gas chromatograph equipped with an AS 3000 autosampler and coupled to a TSQ Quantum XLS mass spectrometer (both 
Thermo-Scientific, Bremen, Germany). The GC instrument was fitted with a TG-5 MS col umn ( $60 \mathrm{~m}, 0.25 \mathrm{~mm}$, i.d., $0.25 \mu \mathrm{m}$ film thickness) from Thermo, Bellefonte, PA, USA. Samples were injected at $40{ }^{\circ} \mathrm{C}$ (held $1 \mathrm{~min}$ ) and the oven was programmed to $120^{\circ} \mathrm{C}$ at $30{ }^{\circ} \mathrm{C} / \mathrm{min}$ and then to $300{ }^{\circ} \mathrm{C}$ (held 70 min) at $3{ }^{\circ} \mathrm{C} / \mathrm{min}$. Each sample was dissolved in toluene and $2 \mu l$ were injected in splitless mode at $280{ }^{\circ} \mathrm{C}$; the carrier gas was $\mathrm{He}$ at $1.0 \mathrm{ml} / \mathrm{min}$. The MS instrument was operated in the electron ionization (EI) mode at 70 $\mathrm{eV}$ and scanned from $\mathrm{m} / \mathrm{z} 50$ to 600 . Assignment of bile acids was based on retention times and mass spectra in literature data (Elhmmali et al., 1997; Tyagi et al., 2008). The concentrations are normalized to total organic carbon and transformed to fluxes $\left(\mathrm{ng} / \mathrm{cm}^{2} / \mathrm{yr}\right)$ using sedimentation rate and dry density.

\section{Results and discussion}

DOC was the sole bile acid throughout the sequence. From bottom to top (Fig. 3), before the Norse settlement, DOC flux was low but constant $\left(0.25 \mathrm{ng} / \mathrm{cm}^{2} / \mathrm{an}\right)$. After ca. $1000 \mathrm{AD}$, it rose to reach a maximum value of $1.77 \mathrm{ng} / \mathrm{cm}^{2} / a n$ around ca. $1200 \mathrm{AD}$, before decreasing to negligible values (< $0.25 \mathrm{ng} / \mathrm{cm}^{2} / \mathrm{an}$ ) from ca. 1400 to ca. $1930 \mathrm{AD}$ (Fig. 3). From then, the flux increased drastically until reaching values approaching those during the Norse period (>1.5 ng/ $\left./ \mathrm{cm}^{2} / \mathrm{an}\right)$. Finally, a slight drop in flux was noted after 2000 AD (Fig. 3).

DOC is a secondary bile acid, bacterially-derived from cholic acid in the intestine of herbivorous and omnivorous mammals, and is then released 
in faeces (Bull et al., 2002). DOC and other bile acids have been largely studied in water, sewage and surficial estuarine sediments to evaluate faecal pollution and determine its source (Elhmmali et al., 1997; Bull et al., 2002; Tyagi et al., 2008). They have al so been studied in anthropogenic and pasture soils (Zocatelli et al., 2012). Bile acids are sparsely reported, however, in ancient environmental samples and were detected in archaeological contexts such as anthropogenic manure palaeosoils (Bull et al., 1999) and Neolithic coprolites (Shillito et al., 2011). Our results constitute the first evidence of the long term persistence of DOC in lake sediments. The presence of DOC in $1700 \mathrm{yr}$ old samples implies that it did not suffer intensive degradation or leaching and could be more extensively examined in sedimentary archives.

DOC evolution remarkably followed that of Sporormiel/a spp. spores (Pearson test; $R^{2}$ 0.6, $p_{\text {value }} 0.0005 ;$ Fig. 3). Low levels $\left(1 \mathrm{~N} / \mathrm{cm}^{2} / a n\right)$ were noted from ca. $300 \mathrm{AD}$ up to ca. $1000 \mathrm{AD}$, except for a single sample with a higher value $\left(7 \mathrm{~N} / \mathrm{cm}^{2} / \mathrm{an}\right)$ at ca. $450 \mathrm{AD}$ that is not an outlier in the DOC data. Then, as for DOC, Sporormiel/a flux increased slightly after ca. 1000 AD and more strongly so after ca. $1100 \mathrm{AD}$, until reaching a maximum (10 $\mathrm{N} / \mathrm{cm}^{2} / \mathrm{an}$ ) around $1200 \mathrm{AD}$. After then, Sporormiel/a flux decreased to 2 $\mathrm{N} / \mathrm{cm}^{2} / a n$ and remained relatively stable from ca. 1450 to ca. $1920 \mathrm{AD}$, when the flux increased rapidly until rising to the highest value of $64 \mathrm{~N} / \mathrm{cm}^{2} / a n$. Thus, both DOC flux and Sporormiella spp. flux were high during the two periods of intensive grazing as a result of pastoral activity. Moreover, they were low but not zero during the two periods when no animal husbandry 
was revealed in the catchment (before the Norse colonization and the LIA), with noticeably lower levels after the Norse settlement than before for both tracers.

Coprophilous fungal spores commonly grow on animal dung, especially of herbivores (Van Geel et al., 2003; Gauthier et al., 2010). Sporormiel/a spp. grazing activity biomarkers (Davis and Shafer 2006). Because their abundance in sediments depends on many factors such as humidity, temperature and competition between species, it is currently difficult to quantitatively relate their abundance to the intensity of grazing activity in the catchment (Baker et al., 2013). Similarly, no study has proposed to relate concentration of faecal biomarkers to livestock size in a catchment. It is thus remarkable that, except for the most recent sediments, the amplitude of variation in both tracers was comparable. This would suggest that a similar quantitative control is exerted on both tracers.

Another striking feature of our record lies in the relatively stable and nonzero levels of DOC and Sporormiel/a spp. spores before (between ca. 300 AD and ca. 1000 AD) and after (between ca. 1400 and ca. 1900 AD) the Nor se settlement. The background of DOC and Sporormiel/a spp. spores could therefore be attributed to wild herbivores, especially reindeer, that are the only large wild herbivores attested to, before and during the Norse settlement, around Igaliku (Arneborg et al., 2012). Higher DOC fluxe values during the Norse and Danish periods are interpreted as higher grazing pressure in Igaliku catchment. Conversely, significantly lower DOC and coprophilous fungal spores flux values after the Norse settlement than 
before would suggest a severe reduction in the population of reindeer around Igaliku after the Norse period. Such a reduction could result from a combination of (i) direct reduction of the reindeer population by $\mathrm{N}$ or se hunting; (ii) reduction in reindeer food resources due to intensive grazing and a diminution in tree and shrub cover (Gauthier et al., 2010) and degradation of soil (an increase in denudation rate is pointed out by Massa et al., 2012); (iii) the dimatic deterioration in the LIA. Considering that DOC flux did not return to pre-Norse levels before the Danish recolonization, one could conclude to long term impact of Norse activities on Greenland ecosystems.

\section{Conclusions}

DOC, a faecal biomarker, was detected in Southern Greenlandic lacustrine sediments dated back to the last two millennia. Higher flux values occurred in sediments deposited during the two phases of livestock breeding in the catchment: the Norse settlement during medieval times and modern Danish colonization. DOC and Sporormiella spp. spore flux values were well correlated, suggesting a quantitative relationship between these two biomarkers. If so, lower DOC flux after the Norse occupation than before may be interpreted as a significant and permanent impact on wild grazing animals. Identification and quantification of faecal biomarkers, especially bile acids, in lacustrine sedimentary archives are thus expected to provide information on past dynamics of pastoralism. 


\section{Acknowledgements}

The research was supported by the University of Franche-Comté, the CNRS, the French Polar Institute (IPEV) and the ANR CEP\&S "Green Greenland" Project (ANR-10-CEPL-0008). The authors also wish to thank two anonymous reviewers for constructive comments.

\section{References}

Arneborg, J., Lynnerup, N., Heinemeier, J., Møhl, J., Rud, N., Sveinbjörnsdóttir, Á.E., 2012. Norse Greenland dietary economy ca. AD 980-ca. AD 1450: Introduction. Journal of the North Atlantic 3, 139.

Baker, A.G., Bhagwat, S.A., Willis, K.J., 2013. Do dung fungal spores make a good proxy for past distribution of large herbivores? Quaternary Sciences Review 62, 21-31.

Bull, I.D., Lockheart, M.J., Elhmmali, M.M., Roberts, D.J., Evershed, R.P., 2002. The origin of faeces by means of biomarker detection. Environment International 27, 647-654.

BulI, I.D., Simpson, I.A., Van Bergen, P.F., Evershed, R.P., 1999. Muck'n molecules: organic geochemical methods for detecting ancient manuring. Antiquity 73, 86-96.

D’Anjou, R.M., Bradley, R.S., Balascio, N.L., Finkelstein, D.B., 2012. Climate impacts on human settlement and agricultural activities in northern Norway revealed through sediment biogeochemistry. Proceedings of the National Academy of Sciences USA 109, 2033220337.

Davis, O.K., Shafer, D.S., 2006. Sporormiel/a fungal spores, a palynological means of detecting herbivore density. Palaeogeography, Pal aeodimatology, Pal aeoecology 237, 40-50.

Dugmore, A.J., McGovern, T.H., Vésteinsson, O., Arneborg, J., Streeter, R., Keller, C., 2012. Cultural adaptation, compounding vulnerabilities and conjunctures in Norse Greenland. Proceedings of the National Academy of Sciences USA 109, 3658-3663.

Elhmmali, M.M., Roberts, D.J., Evershed, R.P., 1997. Bile acids as a new class of sewage pollution indicator. Environmental Science and Technology 31, 3663-3668.

Gauthier, E., Bichet, V., Massa, C., Petit, C., Vannière, B., Richard, H., 2010. Pollen and non-pollen palynomorph evidence of medieval 
farming activities in southwestern Greenland. Vegetation History and Archaeobotany 19, 427-438.

Giguet-Covex, C., Pansu, J., Arnaud, F., Rey, P.-J., Griggo, C., Gielly, L., Domaizon, I., Coissac, E., David, F., Choler, P., Poulenard, J., Taberlet, P., 2014. Long livestock farming history and human landscape shaping revealed by lake sediment DNA. Nature Communications 5, 3211.

Jardé, E., Gruau, G., Mansuy-Huault, L., 2007. Detection of manure-derived organic compounds in rivers draining agricultural areas of intensive manure spreading. Applied Geochemistry 22, 1814-1824.

Jacob, J., Disnar, J.-R., Arnaud, F., Chapron, E., Debret, M., Lallier-Vergès, E., Desmet, M., Revel-Rolland, M., 2008. Millet cultivation history in the French Alps as evidenced by a sedimentary molecule. Journal of Archaeological Sciences 35, 814-820.

Jacob, J., Disnar, J.-R., Boussafir, M., Spadano Albuquerque, A.L., Sifeddine, A., Turcq, B., 2005. Pentacyclic triterpene methyl ethers in recent lacusrine sediments (Lagoa do Caçó, Brazil). Organic Geochemistry 36, 449-461.

Lavrieux, M., Jacob, J., Disnar, J.-R., Bréheret, J.-G., Le Milbeau, C., Miras, Y., Andrieu-Ponel, V., 2013. Sedimentary cannabinol tracks the history of hemp retting. Geology 41, 751-754.

Massa, C., Bichet, V., Gauthier, É., Perren, B.B., Mathieu, O., Petit, C., Monna, F., Giraudeau, J., Losno, R., Richard, H., 2012. A 2500 year record of natural and anthropogenic soil erosion in South Greenland. Quaternary Science Reviews 32, 119-130.

Oldfield, F., Wake, R., Boyle, J., Jones, R., Nolan, S., Gibbs, Z., Appleby, P., Fisher, E., Wolff, G., 2003. The late-Holocene history of Gormire Lake (NE England) and its catchment: a multiproxy reconstruction of past human impact. The Holocene 13, 677-690.

Shillito, L.-M., Bull, I.D., Matthews, W., Almond, M.J., Williams, J.M., Evershed, R.P., 2011. Biomolecular and micromorphological analysis of suspected faecal deposits at Neolithic Çatalhöyük, Turkey. Journal of Archaeological Sciences 38, 1869-1877.

Tyagi, P., Edwards, D.R., Coyne, M.S., 2008. Use of sterol and bile acid biomarkers to identify domesticated animal sources of fecal pollution. Water Air Soil Pollution 187, 263-274.

Van Geel, B., Buurman, J., Brinkkemper, O., Schelvis, J., van Aptroot, A., Reenen, G., Hakbijl, T., 2003. Environmental reconstruction of a Roman Period settlement site in Uitgeest (The Netherlands), with special reference to coprophilous fungi. Journal of Archaeological Sciences 30, 873-883. 
Zocatelli, R., Lavrieux, M., Disnar, J.-R., Le Milbeau, C., Jacob, J., Bréheret, J.G., 2012. Free fatty acids in Lake Aydat catchment soils (French Massif Central): sources, distributions and potential use as sediment biomarkers. Journal of Soils and Sediments 12, 734-748.

\section{Figure captions}

Fig.1. Location of Lake Igaliku: (a) Map of Greenland with study area in the black circle. (b) Focus on region around the lake including paths (dashed lines), buildings (black rectangles), actual hay fields (grey zone) and the archeological site of Gardar. The catchment delimitation is drawn in dotted lines. (c) Bathymetry of Lake Igaliku and core Iga-2011 location.

Fig.2. Age-depth model for Iga-2007 and correlation between Iga-2007 and Iga-2011 cores (a) The age-depth model is based on ${ }^{14} \mathrm{C},{ }^{210} \mathrm{~Pb}$ and ${ }^{137} \mathrm{Cs}$ data (dots), according to Massa et al. (2012). (b) Correlation is based on magnetic susceptibility data.

Fig.3. Evolution of DOC (black line) and coprophilous fungal spores flux (grey line) throughoutt the last $2 \mathrm{kyr}$ in sediments from Lake Igaliku. The timeline indicates the different climatic and anthropogenic phases. The nuance of grey shows the anthropogenic impact (the dark area, strong impact; white, no impact) and in the climatic zones, the nuance of grey is an indicator of temperature (dark area, warmer than elsewhere). 


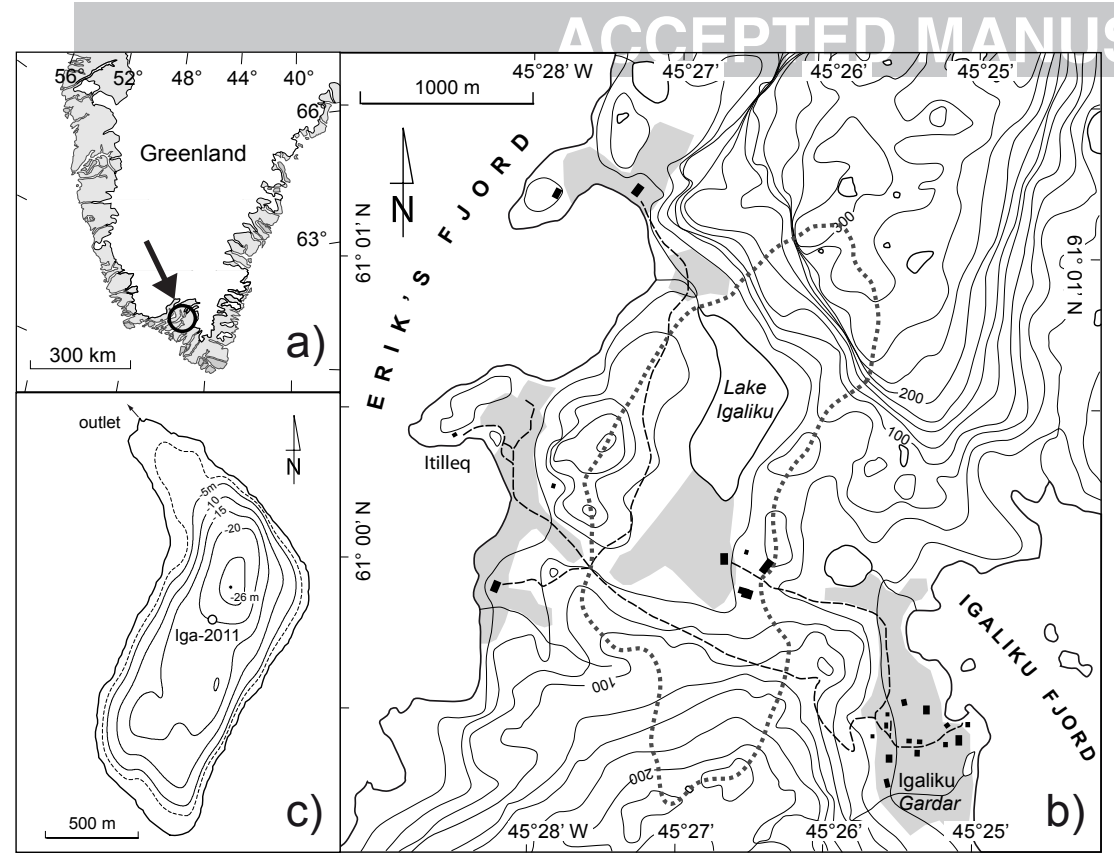




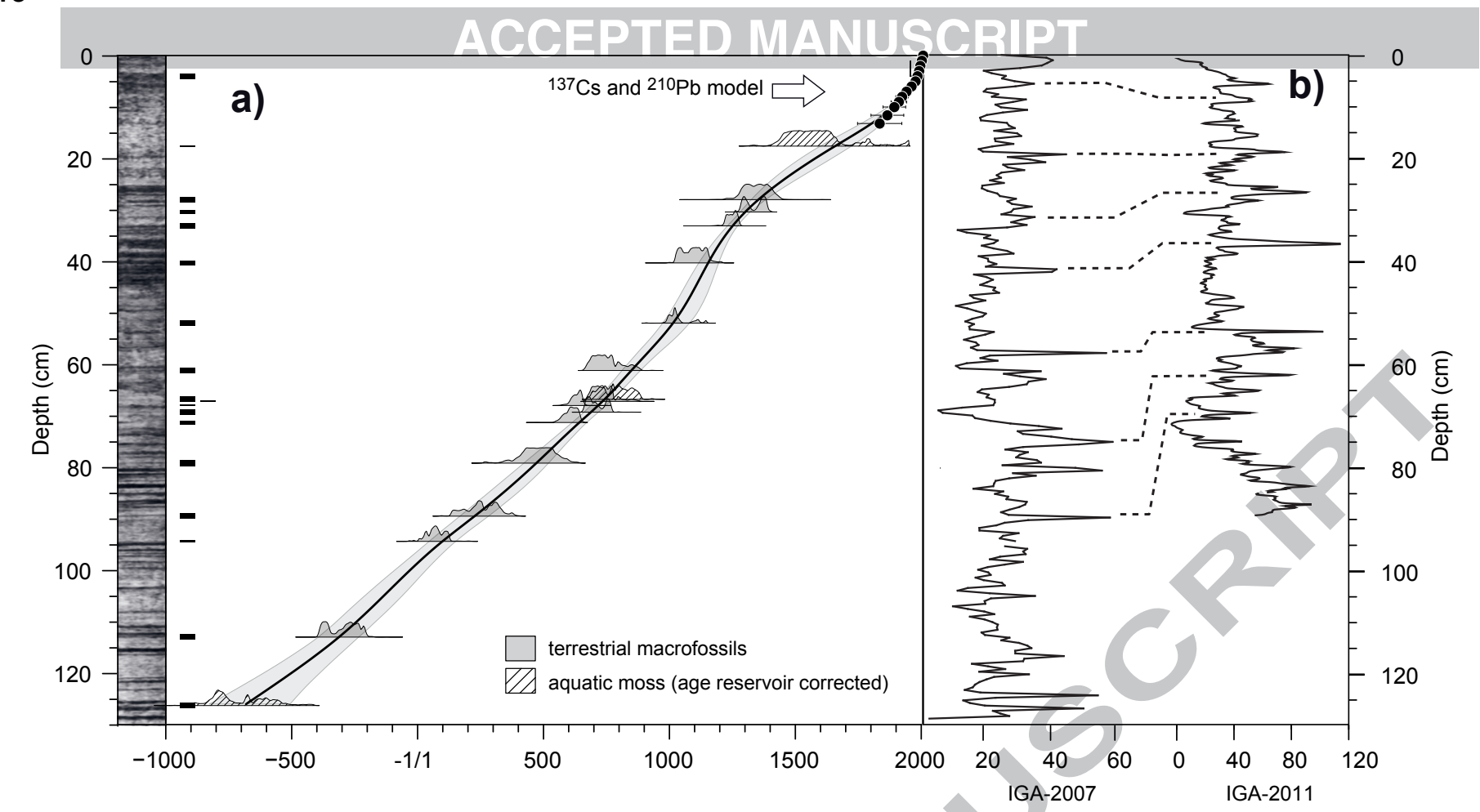

Age (cal yrs AD)

Magnetic Susceptibility

(S.I.) 


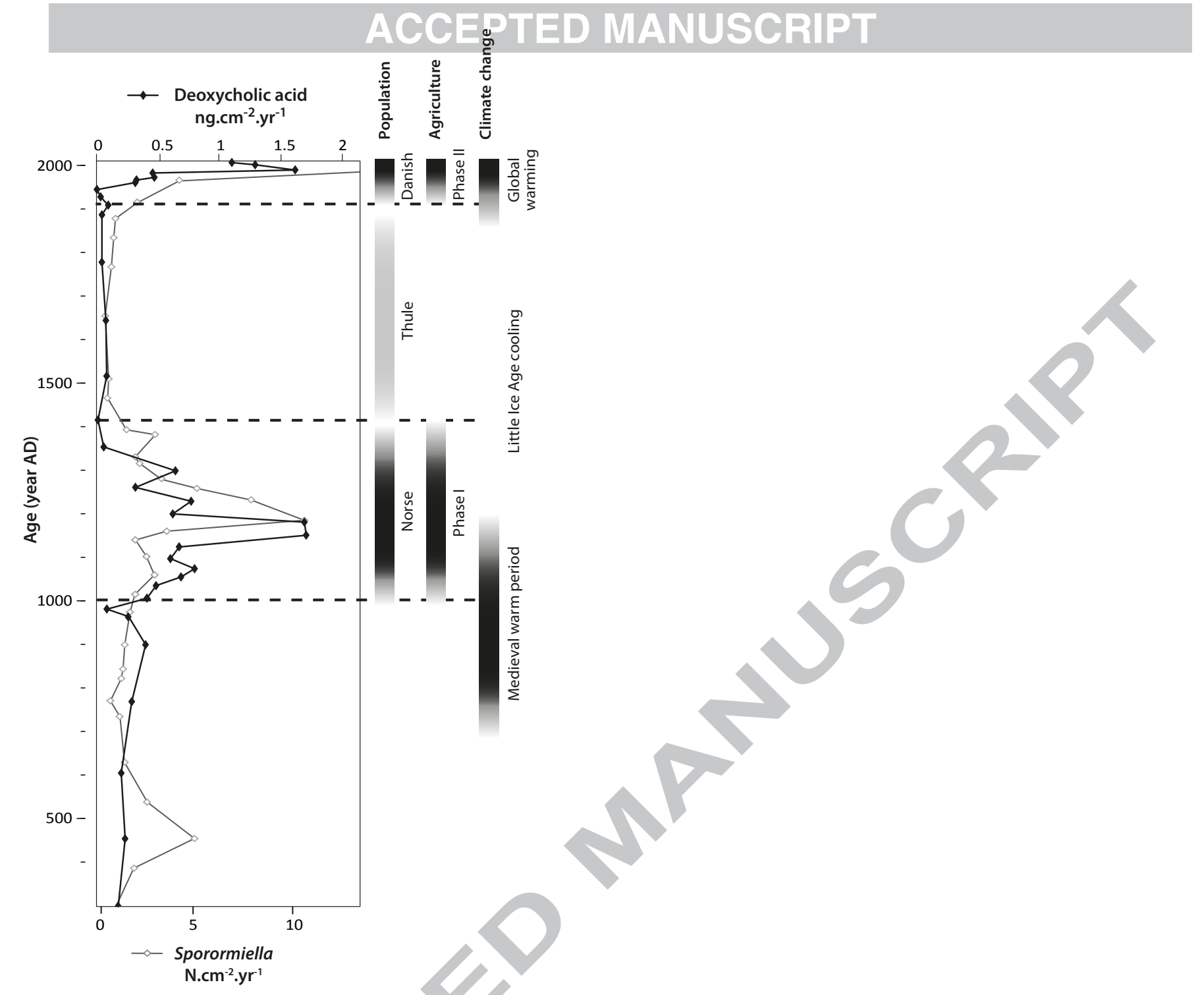

